e-ISSN 2580-5118

p-ISSN 2548-1827

\title{
ANALISIS PENGARUH PENERAPAN MANAJEMEN STRATEGIK DAN PENYUSUNAN ANGGARAN PEMILUKADA TERHADAP KINERJA LEMBAGA PENYELENGGARA PEMILU
}

\author{
Agus Defri Yando ${ }^{1}$, Syarif Hidayah Lubis ${ }^{2}$. \\ Dosen Universitas Putera Batam \\ email: aguspeace89@gmail.com
}

\begin{abstract}
KPU in the city of Batam is a state institution that organizes public services in the ownership sector. In planning its duties and functions, KPU Batam has compiled a strategic plan, annual work plan and performance agreement. The implementation of strategic management and budget preparation is considered to affect the performance of the institutions both financial performance and program performance. This research is a quantitative descriptive study with a correlational approach. The variables tested in this study were the application of Stratejic management and budget drafting as independent variables and performance achievements as dependent variables. This research uses secondary data consisting of institutional documents in the form of strategic plan comments, annual work plans, performance reports and budget realization. This research shows that the variable (X1) is the application of strategic management that is engaged towards the performance of the board. Variable (X2) Implementation of budget drafting that affects the institution's performance.
\end{abstract}

Keywords: strategic management, budget drafting, institutional performance

\section{PENDAHULUAN}

Undang Undang Nomor 25 Tahun 2004 Tentang Sistem Perencanaan Pembangunan Nasional mengharuskan setiap kementerian atau lembaga negara membuat perencanaan strategis yang dituangkan dalam sebuah dokumen yang disebut dengan Rencana Strategis (Renstra) Kementrerian/Lembaga Negara. Renstra tersebut memuat memuat visi, misi, tujuan, strategi, kebijakan, program, dan kegiatan pembangunan sesuai dengan tugas dan fungsi kementerian/lembaga yang disusun dengan berpedoman pada Rencana Pembangunan Jangka Menengah Nasional (RPJM) atau Rencana Pembangunan Jangka Menengah Daerah (RPJMD) yang bersifat indikatif. Renstra tersebut menjadi acuan bagi setiap lembaga negara dalam menyusun program dan kegiatan lembaga negara tersebut dalam suatu dokumen yang disebut dengan Rencana Strategis (Renstra) secara periodik maupun Rencana Kerja (Renja) pada setiap tahun anggaran.

Komisi Pemilihan Umum (KPU) merupakan lembaga negara yang diberikan kewenangan oleh undang-undang untuk menyelenggaraan pemilu. Pemilu tersebut termasuk pemilu legislatif pada semua tingkat (DPR, DPD dan DPRD), pemilihan presiden dan pemilihan kepala daerah. Dalam menyelenggarakan tugasnya sebagai penyelenggaran pemilu, KPU menjalankan serangkaian program, tahapan dan kegiatan penyelenggaraan pemilu dalam sebuah siklus yang disebut dengan siklus penyelenggaraan pemilu (election circle) yang terdiri atas tahapan pra pemilihan (pre election period), tahapan pelaksanaan pemilihan (election period) dan tahapan pasca pemilihan (post election period). Tahapan tersebut dilakukan secara berkesinambungan (sustainable) sehingga diharuskan untuk melakukan perencanaan secara matang pada setiap tahapan penyelenggaraan pemilu tersebut.

Dalam Renstra Tahun 2015-2019, KPU telah menetapkan visinya untuk menjadi penyelenggara pemilu yang mandiri, professional, dan berintegritas untuk terwujudnya pemilu yang langsung, umum, bebas, rahasia serta jujur dan adil. Pernyataan visi tersebut merupakan gambaran tegas dari komitmen KPU untuk menyelenggarakan pemilu yang jujur, adil, transparan, akuntabel dan mandiri serta dilandasi dengan mekanisme kerja yang efektif, efisien, berpegang teguh pada etika profesi dan jabatan, berintegritas tinggi dan berwawasan nasional sehingga menjadikan KPU sebagai lembaga penyelenggara pemilu yang terpercaya dan professional. Di samping itu, KPU juga berkomitmen penuh untuk ikut mengambil bagian dari 
upaya meningkatkan kualitas sumber daya manusia Indonesia khususnya di bidang politik kepemiluan.

Untuk mencapai visi ideal tersebut, KPU dalam Renstra Tahun 2015-2019 menekankan paling tidak tiga misi penting yaitu (1) menyusun Regulasi di bidang pemilu yang memberikan kepastian hukum, progesif, dan partisipatif, (2) meningkatkan kualitas pelayanan pemilu, khususnya untuk para pemangku kepentingan dan umumnya untuk seluruh masyarakat serta (3) mewujudkan penyelenggara Pemilu yang efektif dan efisien, transparan, akuntabel, serta aksesabel. Visi ideal dan misi penting tersebut harus secara konsisten dilaksanakan oleh KPU pada setiap tahapan penyelenggaraan pemilu baik pada pelaksanaan pemilu.

Dari berbagai tahapan penyelenggaraan pemilu, salah satu tahapan yang paling krusial adalah perencanaan anggaran pemilu. Hal ini didasari pada fakta bahwa penyelenggaraan pesta demokrasi tersebut membutuhkan anggaran yang relatif besar, melibatkan banyak pihak sebagai unsur penyelenggara, mengharuskan penyusunan anggaran yang sesuai dengan mekanisme dan peraturan perundangan yang berlaku serta mengharuskan adanya proses audit dan pelaporan keuangan yang dapat sepenuhnya dapat dipertanggungjawabkan. Di samping itu, KPU dalam menyusun anggaran tersebut harus melibatkan partisipasi publik dan juga unsur pemerintah lainnya serta tetap memastikan prinsip efisiensi dan efektifitas penggunaan anggaran diterapkan.

Perencanaan anggaran pemilu tentunya memiliki perbedaan pada setiap jenis dan tingkatan penyelenggaraan pemilu. Jika pemilihan umum dilakukan pada tingkat nasional seperti pemilihan legislatif dan pemilihan presiden hampir seluruhnya pembiayaannya bersumber dari APBN sedangkan untuk penyelenggaraan pemilihan kepala daerah baik pemilihan gubernur/wakil gubernur maupun pemilihan bupati/wakil bupati dan pemilihan walikota dan wakil walikota pembiayaannya hampir sepenuhnya berasal dari APBD provinsi maupun APBD Kabupaten/APBD Kota. Karena KPU merupakan lembaga negara yang bersifat nasional dan mandiri sedangkan pendanaan pemilu besumber dari APBD maka pendanaan yang digunakan KPU dalam penyelenggaraan pemilu tersebut disebut dengan Hibah Daerah yang secara resmi dibuat dalam sebuah nota kesepahaman antara pengguna anggaran (KPU) dengan pemberi anggaran (Pemerintah Daerah yang disebut dengan Naskah Perjanjian Hibah Daerah (NPHD).

Undang-Undang Nomor 8 Tahun 2015, mengamanatkan penyelenggaraan Pemilukada baik Pemilu Gubernur, Pemilu Bupati dan Pemilu Walikota dilaksanakan secara serentak di Indonesia. Pelaksanaan pemilu tersebut didasarkan kepada perhitungan mengenai Akhir Masa Jabatan (AMJ) kepala daerah dengan perincian Pilkada serentak gelombang pertama dilaksanakan untuk pemilihan kepala daerah dan wakil kepala daerah yang memasuki akhir masa jabatan 2015 dan semester pertama 2016, gelombang kedua untuk akhir masa jabatan kedua tahun 2016 dan seluruh daerah yang AMJ jatuh pada 2017 sedangkan gelombang ketiga tahun 2018 dilakukan untuk akhir masa jabatan tahun 2018 atau semester pertama tahun 2019 (Perludem, 2015). KPU sebagai penyelenggara pemilu secara nasional telah melaksanakan 3 (tiga) kali penyelenggaraan pemilukada serentak masing-masing pada tahun 2015, tahun 2017 dan tahun 2018. Pemilukada serentak tahap pertama telah dilangsungkan pada tanggal 15 Desember 2015 yang diikuti oleh 269 daerah yang terdiri atas 9 provinsi, 224 kabupaten dan 36 kota. Sedangkan untuk pemilukada tahan kedua telah dilangsungkan pada tahun 2017 atau tepatnya tanggal 15 Februari 2017 yang diikuti oleh 101 yang terdiri atas 7 provinsi, 76 kabupaten, dan 18 kota. Sedangkan untuk tahap 3 (tiga) atau terakhir dilangsungkan pada tanggal 27 Juni 2018 yang akan di ikuti oleh 171 daerah yang terdiri atas 17 provinsi, 115 kabupaten dan 39 kota.

Kota Batam telah menyelenggarakan Pemilukada pada tahun 2015 serta telah menetapkan pasangan calon terpilih. KPU Kota Batam pada satu sisi telah sukses menjalankan tugasnya namun pada sisi yang lain menyangkut kegiatan pada tahapan pra pemilu maupun pada tahapan pasca pemilu khususnya terkait dengan manajemen dalam pelaksanaan program penyelenggaraan kegiatan maupun kinerja lembaga perlu untuk dikaji. Atas dasar tersebut, kajian ini selanjutnya mengambil tema tentang manajemen stategik pemilukada dan kinerja 
lembaga dalam sebuah judul : "ANALISIS PENGARUH MANAJEMEN STRATEGIK DAN PENYUSUNAN ANGGARAN PEMILUKADA TERHADAP KINERJA LEMBAGA PENYELENGGARA PEMILU”.

\section{Tujuan Penelitian}

Untuk mengetahui dan menganalisis pengaruh penerapan manajemen strategik dan penyusunan anggaran terhadap kinerja lembaga penyelenggara pemilu Kota Batam.

\section{TINJAUAN PUSTAKA \\ Manajemen Strategik}

Perencanaan merupakan sebuah proses atau juga kegiatan untuk mendefinisikan tujuan organisasi, membuat strategi untuk mencapai tujuan dan mengembangkan rencana aktivitas kerja organisasi. Perencanaan ini menjadi aspek krusial bagi semua lembaga negara dalam menjalankan tugas pokok dan fungsinya sehingga tujuan yang diharapkan dapat dirancang, dipantau, dikontrol dan diterapkan. Perencanaan tersebut juga harus dibuat dalam sebuah dokumen formal setiap periode waktu tertentu dan sebaiknya dilakukan secara berkesinambungan. Karena pentingya aspek perencanaan ini maka tidak salah jika Benjamin Franklin mengungkapkan bahwa "if you fail to plan, you are planning to fail" (KPU, 2015).

John A. Pearce II dan Richard R Robinson (Alianto, 2005:36-56) memberikan pemahaman bahwa manajemen strategis merupakan sekumpulan keputusan dan tindakan yang merupakan hasil dari formula dan implementasi dari rencana yang telah didesain sebelumnya dan ditujukan untuk mencapai tujuan sebuah organisasi. Tindakan tersebut termasuk memformulasikan tujuan yang dituangkan dalam sebuah visi organisasi, menilai lingkungan dan potensinya, mengidentifikasi setiap pilihan strategi dan memilih strategi, mengembangkan visi serta mengevaluasi keberhasilan dari strategi yang telah diimplementasikan Alianto (2005).

Tujuan manajemen strategis ini dilakukan untuk meninjau kembali kekuatan, kelemahan, peluang dan ancaman terhadap tugas pokok dan fungsi lembaga. Karena itu manajemen strategis itu hendaknya rumusannya selalu diperbaharui agar sesuai dengan perkembangan, menjawab lingkungan eksternal yang dinamis, melakukan inovasi layanan agar selalu sesuai dengan keinginan publik,melaksanakan dan mengevaluasi strategi yang dipilih secara efektif dan efisien; mengevaluasi kinerja, meninjau dan mengkaji ulang situasi serta melakukan berbagai penyesuaian dan koreksi jika terdapat penyimpangan di dalam pelaksanaan strategi. Sedangkan manfaat manajemen strategik adalah untuk dapat menyelesaikan masalah yang dihadapi organisasi lebih cepat dan lebih tepat; menjadi lebih peka dalam menjawab ancaman yang datang dari luar organisasi; membuat keputusan terbaik dikarenakan interaksi kelompok mengumpulkan berbagai strategi yang lebih besar; kerjasama dalam tim karyawan di dalam perumusan strategi akan dapat memperbaiki pengertian mereka atas penghargaan produktivitas di dalam setiap perencanaan strategi dan dengan demikian dapat mempertinggi motivasi kerja mereka. Pada bahagian lain Manajemen strategis menurut Lumpkin \& Eishner (Sampurno, 2011) memiliki paling tidak 4 (empat) atribut penting yaitu (1) dibuat terarah langsung pada tujuan organisasi, (2) melibatkan berbagai stakeholder dalam pengambilan keputusan, (3) dihubungkan pada perspektif jangka pendek maupun jangka panjang, dan (4) menengarai perlunya pelaksaanaan kegiatan dengan prinsip efisiensi dan efektifitas.

\section{Penyusunan Anggaran}

Organisasi sektor publik selama ini sering dihubungkan dengan berbagai bentuk patologi birokrasi seperti digambarkan tidak produktif, tidak efisien, selalu rugi, rendah kualitas, miskin inovasi dan kreativitas, serta berbagai kritikan lainnya. Munculnya kritik keras yang ditujukan kepada organisasi-organisasi sektor publik tersebut kemudian menimbulkan gerakan untuk melakukan reformasi manajemen sektor publik dimana salah satu gerakan adalah dengan munculnya konsep New Public Management (NPM) (Indrawati, 2010). Sektor yang paling banyak mendapat sorotan terkait dengan NPM ini adalah sektor anggaran mulai dari tahapan penyusunan anggaran, penggunaan anggaran, monitoring penggunaan anggaran sampai pada evaluasi penganggaran.

Mulyadi dalam Basri (2013, 202-212) memberikan pemaknaan bahwa anggaran merupakan suatu rencana kerja yang dinyatakan secara kuantitatif yang diukur dalam satuan moneter. Anggaran publik selain merupakan suatu rencana kerja yang dinyatakan secara 
kuantitatif juga mencakup periode jangka waktu satu tahun. Anggaran ini merupakan perencanaan jangka pendek suatu organisasi yang menerjemahkan berbagai program ke dalam rencana keuangan tahunan yang lebih kongkret. Robert \& Vijay (2009:75) menyatakan bahwa penyusunan anggaran mempunyai 4 (empat) tujuan utama yaitu (1) menyesuaiakan rencana strategis, (2) membantu mengkoordinasikan aktivitas dari beberapa bagian organisasi, (3) menugaskan tanggung jawab kepada manajer, untuk mengotorisasi jumlah yang berwenang untuk mereka gunakan, dan untuk menginformasikan kepada mereka mengenai kinerja yang diharapkan dari mereka, serta (4) memperoleh komitmen yang merupakan dasar untuk mengevaluasi kinerja aktual manajer.

Affandi \& Wulandari dalam Fakhry et. al (2014:189-124) menunjukkan bahwa proses penganggaran yang dilakukan oleh pemerintah saat ini lebih mendorong tumbuhnya nilai-nilai materialitas dibandingkan dengan nilai-nilai sosial. Di sinilah diperlukan salah satunya kearifan lokal dalam penyusunan anggaran tersebut. Dalam rangka pelaksanaan penganggaran berbasis kinerja (PBK), pada dasarnya ingin mengkaitkan antara pembiayaan dengan hasil dari program yang dijalankan oleh pemerintah. Pada beberapa kajian maupun literatur, menjelaskan pentingnya peran penghitungan biaya dalam mendukung penganggaran berbasis kinerja.

\section{Pemilukada}

Pemilu Kepala Daerah (Pemilukada) sejak regulasi UU Nomor 1 Tahun 2015 tentang Penetapan Perpu Nomor 1 Tahun 2014 tentang Pemilihan Gubernur, Bupati dan Walikota Menjadi UU mengamanatkan bahwa penyelenggaraan Pemilukada baik Pemilu Gubernur, Bupati dan Walikota dilaksanakan secara serentak di Indonesia. Pelaksanaan pemilukada serentak didasarkan kepada perhitungan mengenai Akhir Masa Jabatan (AMJ) kepala daerah seIndonesia dengan perincian Pilkada serentak gelombang pertama dilaksanakan untuk pemilihan kepala daerah dan wakil kepala daerah yang memasuki akhir masa jabatan 2015 dan semester pertama 2016, gelombang kedua untuk akhir masa jabatan kedua tahun 2016 dan seluruh daerah yang AMJ jatuh pada 2017 sedangkan gelombang ketiga tahun 2018 dilakukan untuk akhir masa jabatan tahun 2018 atau semester pertama tahun 2019 (Perludem, 2015).

\section{Kinerja Lembaga}

Secara umum kinerja atau performance diartikan sebagai hubungan antara hasil kerja secara nyata maupun fisik dengan masukan sebenarnya atau perbandingan antara hasil masukan dengan keluaran (Hakim \& Wuryanto, 2014: 1-18). Kinerja ini merupakan sebuah proses yang sistematik untuk menilai perilaku kerja dalam kurun waktu tertentu (Wungu, 2003). Bernardin \& Russel (1993) melihat bahwa kinerja adalah catatan hasil (outcome) yang dihasilkan dari fungsi suatu pekerjaan atau suatu kegiatan tertentu selama satu periode tertentu. Kinerja pada prinsipnya merupakan gambaran mengenai tingkat pencapaian pelaksanaan suatu program kegiatan atau kebijakan dalam mewujudkan sasaran, tujuan, visi, dan misi organisasi yang dituangkan melalui perencanan strategis suatu organisasi (Moeheriono, 2009:60).

Kinerja sebenarnya berasal dari kata-kata job performance dan disebut actual performance atau prestasi kerja atau prestasi sesungguhnya yang telah dicapai. Namun semuanya mempunyai beberapa kesamaan arti dan makna dari pengertian suatu proses penilaian tentang kemauan pekerjaan terhadap tujuan dan jasa, termasuk informasi atas efisiensi serta efektifivitas tindakan dalam mencapai tujuan organisasi. Sedangkan pengukuran kinerja (performance measurement) mempunyai pengertian suatu proses penilaian tentang kemajuan pekerjaan terhadap tujuan dan sasaran dalam pengelolaan sumber daya manusia untuk menghasilkan barang dan jasa, termasuk informasi atas efisiensi serta efektivitas tindakan dalam mencapai tujuan organisasi Moeheriono (2009:60).

Komponen data kinerja terdiri atas: kualitas pekerjaan, kejujuran personil, inisiatif, kehadiran, sikap, kerjasama, kehandalan, pengetahuan tentang pekerjaan, tanggung jawab, dan pemanfaatan waktu (Umar, 2002). Jika organisasi menghendaki karyawan atau pegawainya berprestasi secara optimal, manajemen seharusnya memberikan kesempatan pada mereka untuk melakukan pekerjaan secara optimal pula. Untuk meningkatkan motivasi kerja karyawan atau pegawai maka manajemen bisa merancang agar mereka dapat memiliki semangat yang tinggi dalam bekerja, melalui pemberian kompensasi atau ganjaran (rewards) yang layak dan 
memberikan imbalan yang memadai atas prestasi kerja yang diperoleh karyawan atau pegawai tersebut.

Berdasarkan hasil penelitian Westerman and Bret (2007) terdapat hubungan antara kepribadian, lingkungan dan kinerja pegawai. Pada penelitian tersebut dimensi kepribadian menyenangkan (agreeableness), wawasan ekstra (extraversion) dan ketelitian (conscientiousness) berpengaruh signifikan terhadap lingkungan kerja yang berorientasi hasil sedangkan dua variabel lingkungan kerja, yaitu pemeliharaan sistem (system maintenance) dan dimensi hubungan (relationship dimension), tidak secara signifikan mempengaruhi kepribadian dan kinerja pegawai. Berdasarkan beberapa pendapat tentang kinerja dan prestasi kerja disimpulkan bahwa pengertian kinerja maupun prestasi kerja mengandung substansi pencapaian hasil kerja oleh seseorang. Dengan demikian bahwa kinerja maupun prestasi kerja merupakan cerminan hasil yang dicapai oleh seseorang atau sekelompok orang (Syachroni, 2013). Prestasi kerja tersebut tentunya dapat dinilai baik secara kualitatif maupun kuantitatif (Anwar, 2007).

Dalam organisasi Aatau kelembagaan negara kinerja tersebut selanjutnya dapat dibedakan antara kinerja individu dan kinerja lembaga secara keseluruhan. Kinerja setiap individu atau pegawai dalam lembaga pemerintahan dapat dinilaI melalui capaian kinerja individu yang saat ini dikenal dengan dokumen Satuan Kinerja Pegawai (SKP) yang harus dipenuhi dalam setiap tahun anggaran sedangkan kinerja kelembagaan secara keseluruhan dapat dinilai melalui dokumen yang disebut dengan Laporan Kinerja yang juga dinilai dalam setiap tahun anggaran. Pengukuran kinerja lembaga pemerintah selanjutnya harus diterjemahkan sebagai suatu kegiatan evaluasi untuk menilai atau melihat keberhasilan dan kegagalan pelaksanaan tugas dan fungsi yang dibebankan kepadanya (Nugroho, 2000).

\section{METODE PENELITIAN}

\section{Lokasi dan Waktu Penelitian}

Lokasi dalam penilitian ini dilakukan pada kantor KPU Kota Batam dengan objek penelitian tentang penerapan manajemen strategis dan penyusunan anggaran serta kinerja kelembagaan pada pelaksanaan pemilukada Tahun 2015.

\section{Populasi dan Sampel}

Teknik pengambilan sampel yang digunakan dalam penelitian ini yaitu teknik sampling non probabilitas yaitu teknik yang tidak memberikan peluang atau kesempatan yang sama bagi setiap unsur atau anggota populasi untuk dipilih menjadi sampel. Di dalam penelitian ini menggunakan pengamatan data terhadap Rencana Strategis (Renstra), Rencana Kerja (Renja), Laporan Kinerja (Lapkin), Rekapiulasi SKP Pejabat dan pegawai KPU Kota Batam.

\section{Jenis dan Sumber Data}

Data yang digunakan penulis sebagai pendukung dalam penelitian ini adalah Penelitian ini dirancang menggunakan pendekatan kualititatif (qualitative approach). Data yang digunakan dalam penelitian ini dilakukan dengan pengumpulan dokumentasi berupa pencatatan, perekaman (copying) data-data sekunder khususnya yang ada pada Kantor KPU Kota Batam dan instansi pemerintahan yang relevan..

\section{Defenisi Operasional dan Pengukuran Variabel}

Variabel-variabel dalam penelitian ini adalah Kinerja Lembaga sebagai variabel dependen serta Penerapan Manajemen Strategik dan Penyusunan Anggaran sebagai variabel independen.

Tabel. Operasional Variabel

\begin{tabular}{llll}
\hline \multicolumn{2}{c}{ Variabel } & & \multicolumn{1}{c}{ Indikator } \\
\hline 1. & Penerapan Manajemen & - & Kekuatan yang dimiliki Organisasi \\
& Strategik & - & Kelemahan yang dihadapi Organisasi \\
& $(\mathrm{X} 1)$ & - & Peluang Organisasi Kedepan \\
& & - Kantangan yang Potensial atas organisasi. \\
2. & Penyusunan Anggaran & - Ketepatan Perhitungan Dalam Penyusunan Anggaran \\
3. & $(\mathrm{X} 2)$ & - Ketepatan waktu Penyusunan. \\
& & - Pelibatan Stakeholder dalam Penyusunan Anggaran
\end{tabular}


3. Kinerja Lembaga

(Y)
- Persentase Capaian Program.

- Persentase Penggunaan Anggaran.

- Efesiensi Waktu Pelaksanaan Program

- Efesiensi Waktu Penggunaan Anggaran.

\section{Analisa Data}

Analisis data dilakukan melalui beberapa tahapan yaitu statistic deskriptif, Analisis statistik deskriptif hanya digunakan untuk penyajian dan penganalisisan data yang disertai dengan perhitungan agar dapat memperjelas keadaan atau karakteristik data yang bersangkutan. Analisa data yang digunakan adalah analisa korelasi yaitu yang akan menguji hubungan dan tingkat hubungan antara variabel indenden dengan variabel dependen, dilakukan uji hipotesis dengan uji koefisien determinasi $R^{2}$.

Uji Koefisien Korelasi (R)

Koefisien korelasi digunakan untuk mengukur kuatnya hubungan antar variabel Penerapan Manajemen Strategik (X1) dan Penyusunan Anggaran (X2) terhadap variabel Kinerja Lembaga (Y). Nilai koefisien determinasi adalah di antara nol dan satu.

Uji Determinasi (R2)

Koefisien determinasi digunakan untuk mengetahui besarnya kontribusi variabel Penerapan Manajemen Stategik (X1) Penyusunan Anggaran (X2) dan Kinerja Lembaga (Y). Uji Koefisien Determinasi $R^{2}$ Pada intinya mengukur seberapa jauh kemampuan model dalam menerangkan variasi variabel dependen.

\section{HASIL PENELITIAN DAN PEMBAHASAN \\ Hasil Statistik Deskriptif \\ Penilaian atas Rencana Strategik}

Penilaian atas rencana strategik ini dilakukan melalui penentuan skor pada indikator indikator yang termuat dalam perencanaan strategis dilakukan oleh KPU Kota Batam.

Kekuatan dan Peluang

Penilaian atas Renstra Tahun 2015-2019, dilihat bahwa KPU Batam memiliki kekuatan organisasi yang memadai yaitu kewenangan yang dimiliki dalam melakukan tugas pokok dan fungsinya, struktur organisasi yang memadai, jumlah personil yang cukup untuk melaksanakan kinerjanya serta prasarana kerja yang memadai.

Kelemahan dan Tantangan

Penilaian atas Renstra Tahun 2015-2019, dilihat bahwa KPU Batam memiliki berbagai kelemahan seperti kompetensi SDM yang masih kurang memadai, anggaran untuk semua program belum mencukupi dan juga pelayanan untuk semua jenis layanan yang belum terstandarisasi.

Tantangan KPU Kota Batam sangat banyak diantarany regulasi kepemiluan yang santa dinamis, adanya intervensi politik pada kelembagaan dan juga intervensi non politik seperti mutasi kepegawaian. Mutasi kepegawaian ini menjadi tantangan tersendiri karena banyaknya pegawai KPU Kota Batam yang masih berasal dari instansi pemerintah Kota Batam yang suatu saat dapat ditarik kembali sesuai dengan kebutuhan pemerintah kabupaten.

\section{Penyusunan Anggaran}

Penyusunan anggaran dapat dinilai dengan menggunakan indikator kesesuaian norrmatif penyusunan anggaran, ketepatan perhitungan dalam penyusunan anggaran, ketepatan waktu penyusunan dan pelibatan stakeholders dalam penyusunan anggaran.

Penyusunan anggaran dapat dinilai dengan menggunakan indikator kesesuaian norrmatif penyusunan anggaran, ketepatan perhitungan dalam penyusunan anggaran, ketepatan waktu penyusunan dan pelibatan stakeholders dalam penyusunan anggaran.

Kesesuaian Normatif Penyusunan Anggaran

Untuk memastikan penyusunan anggaran sesuai dengan regulasi dan kaidah penyusunan anggaran beberapa sub-indikator menjadi pertimbangan. Sub indikator itu antara lain jenis regulasi yang digunakan, jumlah regulasi yang digunakan dalam Penyusunan Anggaran serta 
frekuensi rapat kerja penyusunan anggaran. Dengan hasil data sebagaimana dimaksud, maka nilai rata-rata indikator kekuatan kesesuaian normatif penyusunan anggaran secara keseluruhan adalah 75. Nilai ini menunjukkan bahwa secara kelembagaan KPU Kota Batam melakukan penyesuaian normatif dalam penyusunan anggaran dengan baik.

Ketepatan Perhitungan dalam Penyesuaian Anggaran

Ketepatan perhitungan merupakan hal yang krusial dalam penyusunan angaran. Beberapa sub indikator yang dapat dijadikan dalam pengukuran sektor ini antara lain frekuensi revisi anggaran, alasan revisi anggaran, frekuensi pembetulan laporan keuangan dan alasan pembetulan laporan. Dengan hasil data sebagaimana dimaksud di atas, maka nilai rata-rata indikator kekuatan kesesuaian normatif penyusunan anggaran secara keseluruhan adalah 75 . Nilai ini menunjukkan bahwa ketepatan perhitungan dalam penyusunan anggaran pada KPU Kota sudah dilakukan dengan baik.

Ketepatan Waktu Penyusunan Anggaran

Ketepatan waktu penyusunan anggaran penting menjadi indikator dalam penyusunan anggaran. Sub indkator yang dijadikan dalam menilai indikator ini adalah jumlah hari sebelum batas waktu pengiriman usulan anggaran, jumlah surat peringatan pembetulan anggaran dan pelibatan stakeholders dalam penyusunan anggaran. Dengan hasil data sebagaimana dimaksud di atas, maka nilai rata-rata indikator ketepatan waktu penyusunan anggaran secara keseluruhan adalah 62,50. Nilai ini menunjukkan bahwa ketepatan waktu penyusunan anggaran pada KPU Kota belum memadai.

Pelibatan Stakeholders dalam Penyusunan Anggaran Pemilu

Pelibatan banyak pihak dalam penyusunan anggaran memiliki banyak makna dan manfaat. Pertama bahwa semakin banyak stakeholders yang dilibatkan maka peluang untuk melakukan kesalahan penyusunan anggaran semakin kecil. Kedua bahwa satuan kerja memiliki unsur kehati-hatian dalam penyusunan angggaran karena diketahui banyak stakeholders. Keempat, pelibatan stakeholder sekaligus sebagai bentuk sosialisasi tentang struktur anggaran yang dirancang oleh satuan kerja. Terakhir, menunjukkan bahwa satuan kerja berusaha setransparan mungkin dalam perencanaan pembelanjaan barang dan jasa yang akan dilakukan. Sub indikator yang dapat digunakan dalam indikator ini antara lain jumlah rapat kerja/pertemuan penyusunan anggaran dengan pemerintah daerah, jumlah rapat kerja/pertemuan penyusunan anggaran dengan legislatif daerah daerah, jumlah rapat kerja/pertemuan penyusunan anggaran dengan KPU Provinsi/Pusat, jumlah rapat kerja/pertemuan penyusunan anggaran dengan partai politik/kontestan pemilu, jumlah rapat kerja/pertemuan penyusunan anggaran dengan lsm, media atau masyarakat luas. Dengan hasil data sebagaimana dimaksud di atas, maka nilai rata-rata indikator kekuatan kesesuaian normatif penyusunan anggaran secara keseluruhan adalah 55. Nilai ini menunjukkan bahwa pelibatan stakeholders dalam penyusunan anggaran pemilu pada KPU Kota Batam sangat tidak memadai.

\section{Penilaian Kinerja}

Penilaian kinerja KPU Kota Batam tahun 2015 dilakukan dengan menilai persentase capaian kinerja program yang terdiri atas 8 (delapan) sasaran kinerja. Di samping itu, penilaian kinerja juga dilakukan dengan menilai persentase realisasi anggaran dalam periode tahun berjalan.

\section{Capaian Kinerja Program}

Berdasarkan ketentuan dalam renstra KPU Kota Batam terdapat 8 (delapan) sasaran kerja yang harus diukur dan menjadi indikator keberhasilan pelaksanaan program dalam setiap tahun berjalan. ada 2 (dua) indikator yang menjadi sorotan atau karena capaiannya dinilai tidak cukup yaitu Terselenggaranya penataan organisasi, pembinaan dan pengelolaan SDM serta tertib administrasi kepegawaian dan Tersusunnya dan tersedianya produk hukum penyelenggaraan pemilu. Hal ini terjadi karena adanya produk berupa dokumen yang tidak bisa disiapkan oleh KPU Kota Batam atau beberapa kegiatan dalam penyusunan produk hukum yang tidak dapat diselesaikan sampai berakhirnya tahun anggaran.

Capaian Kinerja Anggaran 
Berdasarkan laporan realisasi anggaran KPU Kota Batam Tahun 2015, realisasi anggaran secara total tidak maksimal yakni hanya 66,66 persen dari total anggaran yang bisa direalisasikan. Serapan angaran tertinggi adalah pada belanja pegawai yang hampir mencapai angka $100 \%$. Sedangkan capaian tidak maksimal terdapat pada belanja barang dan jasa.

Capaian kinerja untuk belanja barang dan jasa tidak memadai terutama untuk komponen belanja bahan, honor output kegiatan dan belanja sewa dan jasa lainnya yang tidak mencapai angka 50\% sekalipun. Ada beberapa faktor yang menyebabkan belanja bahan, honor output kegiatan dan belanja sewa dan jasa lainnya capaiannya rendah. Pertama bahwa banyak kegiatan yang berada pada akun anggaran tersebut tidak dapat dilakukan karena minimnya waktu yang dimiliki KPU Batam untuk merealisasikan program tersebut. Kedua, perencanaan penganggaran yang tidak bagus khususnya untuk pengeluaran anggaran yang bersumber dari hibah daerah untuk kepentingan pemilukada.

\section{Hasil Uji Hipotesis}

\section{Analisa Korelasi Antar Variabel}

Korelasi yang dilakukan adalah korelasi regresi dengan dua variabel bebas dan satu variabel terikat. Variabel bebas terdiri atas Penerapan Manajemen Strategik (X1) dan Penyusunan Anggaran (X2) sedangkan Variabel Terikat adalah Kinerja Organisasi (Y). Hasil tabulasi data diuraikan sebagai berikut:

Tabel. Perhitungan Korelasi

\begin{tabular}{|c|c|c|c|c|c|c|c|c|c|}
\hline No & $\mathbf{X}_{\mathbf{1}}$ & $\mathbf{X}_{\mathbf{2}}$ & $\mathbf{Y}$ & $\mathbf{X}_{\mathbf{1}} \mathbf{Y}$ & $\mathbf{X}_{\mathbf{2}} \mathbf{Y}$ & $\mathbf{X}_{\mathbf{1}} \mathbf{X}_{\mathbf{2}}$ & $\mathbf{X}_{\mathbf{1}}{ }^{2}$ & $\mathbf{X}_{\mathbf{2}}{ }^{2}$ & $\mathbf{Y}^{2}$ \\
\hline 1 & 75 & 100 & 100 & 7500 & 10000 & 7500 & 5625 & 10000 & 10000 \\
\hline 2 & 75 & 75 & 100 & 7500 & 7500 & 5625 & 5625 & 5625 & 10000 \\
\hline 3 & 100 & 50 & 100 & 10000 & 5000 & 5000 & 10000 & 2500 & 10000 \\
\hline 4 & 75 & 75 & 100 & 7500 & 7500 & 5625 & 5625 & 5625 & 10000 \\
\hline 5 & 50 & 75 & 70 & 3500 & 5250 & 3750 & 2500 & 5625 & 4900 \\
\hline 6 & 25 & 75 & 70 & 1750 & 5250 & 1875 & 625 & 5625 & 4900 \\
\hline 7 & 25 & 75 & 70 & 1750 & 5250 & 1875 & 625 & 5625 & 4900 \\
\hline 8 & 75 & 50 & 70 & 5250 & 3500 & 3750 & 5625 & 2500 & 4900 \\
\hline 9 & 100 & 75 & 100 & 10000 & 7500 & 7500 & 10000 & 5625 & 10000 \\
\hline 10 & 75 & 75 & 100 & 7500 & 7500 & 5625 & 5625 & 5625 & 10000 \\
\hline 11 & 100 & 50 & 100 & 10000 & 5000 & 5000 & 10000 & 2500 & 10000 \\
\hline 12 & 25 & 100 & 100 & 2500 & 10000 & 2500 & 625 & 10000 & 10000 \\
\hline 13 & 50 & 25 & 64,66 & 3233 & 1616,5 & 1250 & 2500 & 625 & 4180,92 \\
\hline 14 & 25 & 25 & 64,66 & 1616,5 & 1616,5 & 625 & 625 & 625 & 4180,92 \\
\hline$\sum$ & $\mathbf{8 7 5}$ & $\mathbf{9 2 5}$ & $\mathbf{1 2 0 9 , 3 2}$ & $\mathbf{7 9 5 9 9 , 5}$ & $\mathbf{8 2 4 8 3}$ & $\mathbf{5 7 5 0 0}$ & $\mathbf{6 5 6 2 5}$ & $\mathbf{6 8 1 2 5}$ & $\mathbf{1 0 7 9 6 1 , 8 3}$ \\
\hline
\end{tabular}

Hubungan Variabel X1 (Managemen Strategik) dengan Variabel Y (Kinerja Lembaga)

Perhitungan untuk melihat korelasi antara Variabel X1 (Managemen Strategik) dengan Variabel Y (Kinerja Lembaga) diuraikan sebagai berikut:

$$
\mathrm{r}_{\mathrm{y}_{1}}=\frac{\mathrm{n} \sum \mathrm{X}_{1} \mathrm{Y}-\left(\sum \mathrm{X}_{1}\right)\left(\sum \mathrm{Y}\right)}{\sqrt{\left\{\mathrm{n}\left(\sum \mathrm{X}_{1}^{2}\right)-\left(\sum \mathrm{X}_{1}\right)^{2}\right\}\left\{\mathrm{n}\left(\sum \mathrm{Y}^{2}\right)-\left(\sum \mathrm{Y}_{1}\right)^{2}\right\}}}=
$$




$$
\mathrm{r}_{\mathrm{yx}_{1}}=\frac{14(79599,5)-(875)(1209,32)}{\sqrt{\left\{14(65625)-(875)^{2}\right\}\left\{14(107961,63)-(1209,32)^{2}\right\}}}
$$

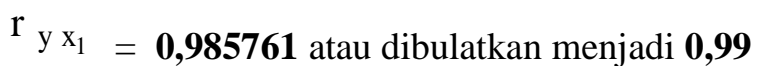

Dengan demikian disimpulkan bahwa hubungan antara kedua variabel adalah positif yang bermarna hubungan kedua variabel langsung dan sangat kuat.

\section{Hubungan Variabel X2 (Penyusunan Anggaran) dengan Variabel Y (Kinerja Lembaga)}

Perhitungan untuk melihat korelasi antara Variabel X2 (Penyusunan Anggaran) dengan Variabel Y (Kinerja Lembaga) diuraikan sebagai berikut:

$$
\begin{aligned}
& \mathrm{r}_{\mathrm{yx}_{2}}=\frac{\mathrm{n} \sum \mathrm{X}_{2} \mathrm{Y}-\left(\sum \mathrm{X}_{2}\right)\left(\sum \mathrm{Y}\right)}{\sqrt{\left\{\mathrm{n}\left(\sum \mathrm{X}_{2}^{2}\right)-\left(\sum \mathrm{X}_{2}\right)^{2}\right\}\left\{\mathrm{n}\left(\sum \mathrm{Y}^{2}\right)-\left(\sum \mathrm{Y}\right)^{2}\right\}}} \\
& \mathrm{r}_{\mathrm{y} \mathrm{x}_{2}}=\frac{14(82483)-(925)(1209,32)}{\sqrt{\left\{14(68152)-(925)^{2}\right\}\left\{14(107961)-(1209,32)^{2}\right\}}} \\
& \mathrm{r}_{\mathrm{y} \mathrm{x}_{2}}=0,996322 \text { atau dibulatkan menjadi } \mathbf{0 , 9 9}
\end{aligned}
$$

Dengan demikian disimpulkan bahwa hubungan antara kedua variabel adalah positif yang bermarna hubungan kedua variabel langsung dan sangat kuat.

Hubungan Variabel X1 (Managemen Strategik) dan X2 (Penyusunan Anggaran) Secara Bersama Sama Terhadap Variabel Y (Kinerja Lembaga)

Perhitungan Hubungan Variabel X1 (Managemen Strategik) dan X2 (Penyusunan Anggaran) secara bersama - sama terhadap Variabel Y (Kinerja Lembaga) diuraikan berikut:

$$
\begin{aligned}
r_{y_{1} x_{2}} & =\sqrt{\frac{r_{y_{x_{1}}}^{2}+r_{y x_{2}}^{2}-2 r_{y_{1}} r_{y_{x_{2}}} r_{x_{1} x_{2}}}{1-r_{x_{1} x_{2}}^{2}}} \\
r_{y_{x_{1} x_{2}}} & =\sqrt{\frac{(0,99)^{2}+(0,99)^{2}-2(0,99)(0,99)(-0,04)}{1-(-0,04)^{2}}} \\
& =\frac{0,981+0,981-2(0,392)}{1-(0,16)} \\
& =\mathbf{0 , 9 6}
\end{aligned}
$$

Angka tersebut menunjukkan bahwa terdapat hubungan yang signifikan antara $X_{1}$ bersama-sama dengan $\mathrm{X}_{2}$ dengan $\mathrm{Y}$ atau terdapat hubungan yang signifikan antara penerapan manajemen strategik dan penyusunan anggaran terhadap efektifitas kinerja lembaga.

\section{Koefisien Determinasi}

Koefisien determinasi antara variabel yaitu Variabel X1 (Managemen Strategik), Variabel X2 (Penyusunan Anggaran) dan Variabel Y (Kinerja Lembaga) diuraikan berikut:

Variabel X1 (Managemen Strategik) Untuk Variabel X1 (Managemen Strategik) dengan korelasinya 0,99 maka koefisein determinasinya $(\mathrm{r} 2)$ adalah 0,98 . Hal ini berarti varians yang terjadi pada managemen strategik adalah $98 \%$ dan $2 \%$ faktor lain ditentukan oleh hal lain tidak dapat diduga.

Variabel X2 (Penyusunan Anggaran) Untuk Variabel X2 (Penyusunan Anggaran) dengan korelasinya 0,99 maka koefisein determinasinya (r2) adalah 0,96 . Hal ini juga berarti varians yang terjadi pada managemen strategik adalah $98 \%$ dan $2 \%$ faktor lain ditentukan oleh hal lain tidak dapat diduga. 


\section{KESIMPULAN DAN SARAN \\ Kesimpulan}

Penelitian ini merupakan penelitian kuantitatif dengan pendekatan studi korelasional untuk melihat hubungan antara penerapan manajemen strategik dan penyusunan anggaran terhadap kinerja Lembaga. Penelitian ini menyimpulkan bahwa:

a. Angka korelasi antara Variabel Penerapan Managemen Strategik (X1) dengan Variabel Kinerja Lembaga (Y) berada pada angka 0,99 yang bermakna hubungan itu langsung dan sangat kuat. Koefisien determinasi adalah 0,98 yang bermakna bahwa ada $2 \%$ faktor lain diluar penerapan manajemen strategik yang berpengeruh terhadap kinerja Lembaga.

b. Angka korelasi antara Variabel Penyusunan Anggaran (X1) dengan Variabel Kinerja Lembaga $(\mathrm{Y})$ berada pada angka 0,99 yang bermakna hubungan itu langsung dan sangat kuat. Koefisien determinasi adalah 0,98 yang bermakna bahwa ada $2 \%$ faktor lain diluar penerapan penyusunan anggaran yang berpengaruh terhadap kinerja Lembaga.

c. Korelasi antara Variabel Penerapan Managemen Strategik (X1) dan Variabel Penyusunan Anggaran (X2) secara bersama-sama terhadap Variabel Kinerja Lembaga (Y) berada pada angka 0,96 yang bermakna korelasinya sangat kuat. Koefisien determinasi adalah 0,92 yang bermakna bahwa ada $8 \%$ faktor lain diluar penerapan manajemen strategis dan penyusunan anggaran yang mempengaruhi kinerja lembaga.

\section{Saran}

Setelah melakukan penelitian dengan pendekatan korelasional untuk melihat hubungan antara penerapan manajemen strategi dan penyusunan anggaran terhadap kinerja lembaga berikut ini disampaikan beberapa saran rekomendasi.

a. Pada Variabel X1 (Penerapan Managemen Strategik) diperoleh informasi bahwa tantangan organisasi sangat besar baik berupa intervensi terhadap lembaga melalui proses mutasi dan sebagainya. Hal ini harus diperhatikan KPU Kota Batam untuk mengusulkan penambahan pegawai organik atau merubah status pegawai DPK menjadi pegawai organik.

b. Pada Variabel X2 (Penyusunan Anggaran), KPU Batam belum banyak melibatkan stakeholdes dalam penyusunan anggaran. Hal ini perlu dilakukan pembenahan dengan melibatkan stakeholders pada penyusunan anggaran di masa yang akan datang. Pelibatan stakeholdes ini bermakna strategis dalam penyusunan anggaran seperti sebagai bentuk sosialisasi, transparansi dan mendapatkan masukan dalam penyusunan anggaran.

c. Pada Variabel Y (Kinerja Lembaga) terlihat bahwa kinerja yang dicapai dengan maksimal mayoritasnya adalah program-program yang sifatnya administratif, umum dan rutin. Serapan anggaran yang dapat direalisasikan hanya mencapai 66,44 persen. Hal ini menjadi perhatian ke depan sehingga anggaran yang sudah dirumuskan dapat dimaksimalkan.

\section{DAFTAR PUSTAKA}

Alianto, Hendra (2005), "Penerapan Manajemen Strategis Pada PT Optik XYZ”, Jurnal BEeSISFO Vol.2 No.1 Juni 2005: 36-56.

Anwar, Prabu AA. (2007) "Manajemen Sumber Daya Manusia Perusahaan”. Bandung. Penerbit : PT. Remaja.

Basri, Ramlah (2013) "Analisis Penyusunan Anggaran dan Laporan Realisasi Anggaran Pada BPM-PD Provinsi Sulawesi Utara" Jurnal Emba, Vol.1 No.4 Desember 2013, Hal.

Fakhry et. al (2014), "Budget Process Pemerintahan Daerah:Menelisik Nilai Kemandaran Atas Perilaku Aktor Anggaran" Jurnal Analisis, Desember 2014, Vol. 3 No. 2 : 189-194.

Flapper, S. D. P., Fortuin, L., \& Stoop, P. P. (1996)Towards consistent performance management systems. International Journal of Operations \& Production Management, 16(7), pp. 27-37.

Hakim \& Abdul (2014), "Model Peningkatan Kinerja Karyawan Melalui Peran Komunikasi dan Motivasi Serta Pengaruhnya Terhadap Kepuasan Kerja", Jurnal Ekobis Vol.15, No.2, Juli 2014 pp 18-21.

Indrawati, Novita (2010), "Penyusunan Anggaran Dalam Era New Public Management: Implementasinya Di Indonesia" Jurnal Riset Akuntansi Dan Bisnis Vol 10 No .2 
Jiwo Wungu \& Brotoharjo, Hartanto (2003), "Tingkatkan Kinerja Perusahaan Anda Dengan Merit Sistem”. Jakarta: Raja Grafindo Pustaka.

Lestari, Niken Ajeng (2017), "Studi Komparasi Penghitungan Biaya Output Dengan Menggunakan Metode Direct Costing Dan Full Costing. Jurnal Sistem Penganggaran Sektor Publik, Direktorat Sistem Penganggaran Direktorat Jenderan Anggaran Kementerian Keuangan RI. Volume I, pp. 43-61

Mangkunegara, Anwar Prabu (2005), "Perilaku dan Budaya Organisasi" Bandung: PT Refika Aditama.

Narbuko \& Achmadi (2016). Metodologi Penelitian. Jakarta: PT. Bumi Aksara.

Nugroho (2000), "Keperawatan Gerontik Edisi Kedua", Jakarta: EGC.

Perludem (2015). Daftar Daerah Yang Melaksanakan Pilkada" http://www.perludem/ diakses tanggal 25 Maret 2018.

Ramly, Amir Tengku \& Syukur, Dudung Abdul (2018), "Strategic Management of Organization+' Development and Civil Service Based Pumpinghr Model at Ibn Khaldun University Bogor", IJBE: Integrated Journal of Business and Economics eISSN: 2549-3280 pp. 64-75.

Robert, A. \& Govindarajan,Vijay (2009), "Sistem Pengendalian Manajemen”, Jakarta: Salemba Empat.

Sampurno (2011), "Manajemen Strategik: Menciptakan Keunggulan Bersaing yang Berkelanjutan". Yogyakarta: Gajah Mada University Press.

Syachroni (2014), "Analisis Faktor-Faktor Yang Mempengaruhi Kinerja Guru SMA Negeri 4 Kota Jambi”, Jurnal Dinamika Manajemen Vol. 1 No. 2 April - Juni 2013 pp. 121-138.

Sugiyono, 2012. Memahami penelitian kualitatif. Bandung : ALFABETA.

Westerman, James W, and Bret L Simmons (2007). The Effect on the Personality Performance Relationship: An Exploratory Study. Journal of Managerial Issues 1 (2) 288-305

Peraturan Perundang Undangan. 